\title{
A PARTICIPACAO DA UNIVERSIDADE DE SAO PAULO NO PROGRAMA INTERNACIONAL GEOSFERA-BIOSFERA (IGBP)
}

De todos os programas científicos já empreendidos pelo Conselho Internacional de Uniões Cientificas (ICSU), O IGBP será - mais ambicioso, o mais variado e, possivelmente, o mais importante para o futuro da humanidade.

Nos anos recentes - finalmente! - as comunidades do mundo todo deram-se conta dos grandes problemas globais que afetam o ambiente, e que ameaçam o seu futuro e sua própria sobrevivência. Tais problemas não têm condições de serem resolvidos de modo unilateral, por qualquer pais ou conjunto de paises, ou por qualquer ramo da ciência, isoladamente. Necessariamente requerem, para uma abordagem adequada, esforços de cooperação internacional, e enfoque interdisciplinar na escala maior, global. Nosso planeta encolheu, com a explosão populacional. Seus recursos naturais são finitos, tornando indispensável a reciclagem da matéria, ou seja, os dejectos de hoje serão os insumos de amanhã. Para manter um certo equilibrio dinâmico, um "steady state" satisfatório, os seres humanos terão que integrar-se como parte harmônica da natureza, da biosfera, do ambiente.

Os objetivos cientificos do IGBP incluem os de coordenar as ações e programas já existentes, no âmbito de várias disciplinas, e de complementá-los com novos estudos sobre as mudanças progressivas que ocorrem na escala do planeta, buscando identificar suas causas naturais e/ou antropogênicas. Além disso, o programa se propõe efetuar previsões objetivas para um futuro a médio prazo (décadas, séculos), buscando atenuar as ameaças existentes ao bem estar e à qualidade de vida da humanidade.

0 programa científico do IGBP ainda não está plenamente definido. Seu núcleo central é inerente aos processos 
meteorológicos, climatológicos e oceanográficos globais, suas interações, seus impactos na biosfera e suas mudanças a curto e médio prazo. Os estudos abrangem, entre outros, o efeito estufa, a redução da camada de ozônio na atmosfera, a evolução do fenômeno El Niño. Por outro lado, o IGBP deverá incluir, de modo crescente, o exame das mudanças globais do passado, tais como se encontram registradas nas rochas sedimentares depositadas em épocas diversas,e também deverá expandir-se para - lado das ciências humanas, em vista das relações mútuas de causa e efeito nas interações com a sociedade, bem como os problemas éticos envolvidos com as tentativas de gerenciamento do ambiente, pelo homem.

Não há dúvida que cabe uma participação expressiva do Brasil no IGBP, não só por causa da sua própria expressão territorial no plano global, mas também pela sua importância politica, tendo como pais emergente do 30 mundo, a garantir que não sejam deixados de lado os problemas do relacionamento Norte/Sul. E não há dúvida que cabe à USP um papel especial, pelo peso especifico relevante que esta Universidade possui na ciência brasileira.

A USP sempre manteve continuado interesse em questões ambientais, seja através de iniciativa de suas Unidades acadêmicas, seja através de esforços coordenados inter-unidades. Por exemplo a Comissão Especial de Proteção Ambiental (CEPA) atua nesta área há vários anos; em março de 88 ocorreu 010 Encontro de Docentes e Pesquisadores da USP sobre Meio Ambiente. Além disso, encontra-se em estudos, pelo Conselho Universitário, a implantação de um Curso de Pós-Graduação em Ciências Ambientais.

Este encontro sobre Mudanças Globais pretende iniciar contatos entre os pesquisadores da USP, interessados na temática, para tornar explicito o potencial da Universidade para participação no IGBP. Posteriormente, desde que seja possivel, e se for julgado desejável, poderá ser organizada uma 
coordenação interna, para articular uma participação coerente e integrada, com ênfase nos esforços interdisciplinares. 0 objetivo final será o de obter a colaboração mútua dos docentes e pesquisadores da USP que se dedicam ao estudo dos processos físicos, quimicos e biológicos que afetam a qualidade de vida e, buscar inseri-los em contextos mais holisticos, mais globais.

\author{
Umberto G. Cordani \\ Diretor \\ Instituto de Geociências
}

